\title{
NATIONAL SOVEREIGNTY AND POPULAR OVEREIGNTY IN THE MAKING OF FINNISH INDEPENDENCE AND THE CIVIL WAR OF 1918
}

\author{
Ilkka Liikanen
}

Abstract In the following an attempt is made to summarize the basic lines of the academic discussion on the character of the Finnish civil war. I pose some questions concerning the nature of the conflict in terms of modern politics. Following the recent discussion on the contradictions of modern political culture, I will ask to what degree the war can be understood in terms of conflicting patterns of national sovereignty and popular sovereignty.

In terms of historiography, the nature of the civil war of 1918 was defined during the interwar and Cold war periods mainly in two opposing ways. In the hegemonic academic tradition, the war was interpreted as a fight for national sovereignty, as the 'war of liberation'. In the discourse close to the labour movement, the conflict was conceptualized as an internal matter, as a social conflict or a 'class war'. First from the 1960s on, there have appeared new interpretations that have tried to cover both aspects of the crises and reassessed in what sense the war can be understood as a struggle for national sovereignty and to what degree it should be seen in the context of an internal social and political conflict.

During the interwar and Cold-War periods, the nature of the civil war of 1918 was defined in Finnish public discussion mainly in two opposing ways. In the white tradition that was hegemonic in public and academic discussion, the war was interpreted as a fight for national sovereignty, as a 'war of liberation'. In the discourse of the labour movement, the conflict was conceptualized as an internal matter, as a 'class war'. First from the 1960s on, there have appeared new interpretations that have tried to cover both aspects of the crises and reassessed in what sense the war can be understood as a struggle for national sovereignty and to what degree it should be seen in the context of an internal social and political conflict. In the following I will try to summarize the basic lines of the academic discussion on the character of the civil war. In the end of my presentation I will try to pose some questions concerning the nature of the conflict in terms 
of modern politics. Following the recent discussion on the contradictions of modern political culture, I will ask to what degree the war can be understood in terms of conflicting patterns of national sovereignty and popular sovereignty.

The Turn of the 1960s In the academic world, it was first the new socio-historical research of the 1960 s that called attention to the social conflicts underlying the civil war and challenged the old concept of a war of liberation, which had dominated the academic tradition for nearly fifty years. Questioning old certainties was not met without confrontation in a country where both the Whites and the Reds had learned for half a century to cherish a single and an incontrovertible truth of their own. In the 1960s the new research on the nature of the events of 1918 aroused a heated surge of emotion and a public polemic, which gradually led to a change in perspectives and an acceptance of the coexistence of different views. During the recent years the discussion about the nature of the war has, however, been again accelerating. After the collapse of the Soviet system, we can recognize a tendency of resurrecting the old war of liberation interpretation arguing that the earlier reevaluation was simply a result of the pressure exerted by the Soviet Union and the 'self-censorship' of the Kekkonen era.

However, this criticism largely misses its target. Contrary to commonly held views, the research of the 1960s was not directly tied to the radicalism of the period, or to the reasoning of the foreign political elite. Nor did the new interpretations totally cast the old war of liberation idea out of the academic research tradition. On the contrary, many prominent names in historical establishment have continuously spoken about the war of liberation from the 1960s to the present day. In this sense, the interpretations of the 1960s did not directly contest the war of liberation concept, but rather complemented it. Pauli Kettunen has characterized this turn by pointing out that in the academic discussion of the 1960s the traditional interpretation that a war of liberation was transformed into a civil war was replaced with a new theory that what started as a civil war became a war of independence. Earlier it was held that the liberation of the nation developed into a civil war when the Reds allied themselves with the enemy. From the 1960s on, the mainstream held that the war perhaps was initially a civil war but its outcome eventually preserved the independence of the nation. In the following I will describe the essential features of this turn in more detail in order to make current trends of discussion better understandable. 
In the Beginning was the Crime After the guns had fallen silent in spring 1918, a large-scale investigation of the Finnish Revolution and the actions of the Finnish Reds was immediately carried out in the form of the investigations for the Tribunal of High Treason. This investigation was decisive for the interpretations of the nature of the war. As the historian Turo Manninen has demonstrated, the idea of a war of liberation was not established as the main ideological argument for the actions of the Whites during the civil war, but only after it. ${ }^{1}$ As much as being an effort to justify White motives when the war broke out in January 1918, the war of liberation interpretation can be seen as an effort to justify the actions of the victors in the aftermath of the war in the spring and summer of 1918. Indeed, the idea of a war of liberation was useful in both senses; in justifying the actions of the Whites it at the same time validated the responsibility of the Reds. In addition to emphasizing the patriotic motives of the victors, the war of liberation concept turned the opposing side into traitors, who were allied with the enemy - and legitimized the harsh acts of revenge and the large-scale executions of the Reds. Thus, the war of liberation interpretation was originally as much an interpretation of cause and guilt.

The so-called liberation-war literature of the interwar period held accordingly that the struggle, which had begun as a war of independence, expanded into a civil war as a result of external Russian influence that took possession of the workers' movement and the lower elements of society. The leaders of the workers' movement adopted the Bolshevik ideals in their hunger for power, and the proletariat masses joined the revolt after having fallen under the spell of Bolshevik agitprop. Accordingly, the events of 1918 were a war of liberation in two senses: in terms of foreign policy it was a fight for independence from Russia, and domestically it was a battle against foreign Russian influence that in the form of Bolshevism had spread into society. ${ }^{2}$

\section{From the Bolshevism Theory to the Radicalization of Inter- pretation from Below After the Second World War academic historiography gradually started introducing differing interpretations for the reasons of the civil war. In his 1957 detailed study Suomi}

${ }^{1}$ T. Manninen, 'Vapaustaistelu, kansalaissota, kapina. Taistelun luonne valkoisessa propagandassa vuonna 1918', Studia Historica Jyväskyläensia, 24 (Jyväskylä, 1982).

${ }^{2}$ On equating Redness and Russianness, see e.g. L. Hyvämäki, Sinistä ja mustaa. Tutkielmia Suomen oikeistoradikalismista (Helsinki, 1971), pp. 78-79. 
vuonna 1918 [Finland in 1918] Juhani Paasivirta pointed out that the leaders of the workers' movement consisted not only of 'those who had fallen under the influence of Bolshevism', but also of 'the Socialist men of Independence', a moderate wing, which advocated parliamentary activity. Contrary to earlier conceptions, he suggested that the desire to follow the path to revolution had been awakened chiefly in the lower ranks of the workers' movement. According to Paasivirta, behind the revolutionary movement were first and foremost the 'masses that had fallen under the spell of the revolutionary ideology'. The most significant actors, according to Paasivirta, were not the party leaders but the Red Guards that followed the example of the Bolsheviks and consciously sought an armed revolution. ${ }^{3}$

In the 1960s the new studies re-evaluated not only the question of guilt but the nature of the responsibility as well. Jaakko Paavolainen's study on red terror (1966) shattered the generalization that the illegalities and acts of violence had been the essential content of the Red activity. Tuomo Polvinen's study Venäjän vallankumous ja Suomi [The Russian Revolution and Finland] (1967) shook the foundations of the war of liberation theory by questioning to what degree the actions of the Red leaders targeted to treason. At the same time Polvinen established a new interpretation of the war of liberation which was based on the idea that in the end it was the White victory that saved the nation's independence. ${ }^{4}$

As the interpretation which emphasized treason and crime, started to fade, the constraints were broken which had suppressed the researchers from associating the revolt with the internal social conflicts in Finnish society. An important opening in this sense was Viljo Rasila's 1968 study Kansalaissodan sosiaalinen tausta [The social background of the Civil War]. Rasila analyzed the occupational and age distribution of the fallen, and interpreted their social position with the help of economic and social statistics depicting Red and White Finland. This crossing of borders had still its limits. Confining the research to a statistical analysis, together with the real novelty of the study, computerized factor analysis, operationalized the research problem purely in social terms that made the revolution appear as a phenomenon completely independent of organized conscious political activity. ${ }^{5}$

${ }^{3}$ J. Paasivirta, Suomi vuonna 1918 (Porvoo, 1957), pp. 54, 60-61, 68, 81.

${ }^{4}$ J. Paavolainen, Poliittiset väkivaltaisuudet Suomessa 1918 I. Punainen terrori (Helsinki, 1966); T. Polvinen, Venäjän vallankumous ja Suomi I (Porvoo, 1967).

${ }^{5}$ V. Rasila, Kansalaissodan sosiaalinen tausta (Helsinki, 1968). 
One of the most important advocates of new perspectives on the revolt was Hannu Soikkanen's History of the Social Democratic Party (1975). Based on broad archive records, he examined in detail the extent of Bolshevik (or anarcho-voluntaristic) views among the leaders of the workers' movement during the years 1917-1918. Soikkanen's study indicated that the leadership of the Social Democratic Party did not represent an active desire for armed revolution, but acted hesitantly and tried to slow things down to the very end. In terms of intellectual history he demonstrated that the Leninist modes of thought and action remained foreign to the leaders of the party, whose thinking was dominated by a passive Kautskian attitude. Like Paasivirta, Soikkanen held that the workers' movement was swept into the path to revolution primarily by the pressure of the masses. Instead of the leaders of the Red Guards, Soikkanen saw the key elements to be the masses that flooded the organizations in 1917 and whose revolutionary enthusiasm the party leadership could not restrain. ${ }^{6}$

Researchers who started their work in the 1960s were inspired by thoughts of national harmony, and sociological ideas of recognizing and regulating social conflicts. They acknowledged that the civil war was caused mainly by domestic social reasons, like food shortage and the plight of the rural tenant farmers and the landless. On the other hand, when emphasizing the social background they did not study the radicalization of the working class in the light of organization and local power relations and political conflicts. The same applies in part to the research of the 1970s with more openly expressed Marxist slant. The researchers of the younger generation sought to construct as materialistic interpretations of class struggle as possible rather than explaining the revolution as a political process. ${ }^{7}$

Concluding the Bolshevikization Discourse In the 1980s an extensive project on the history of Red Finland was completed. It was financed by the Parliament, and in political terms it was rooted

${ }^{6}$ H. Soikkanen, Kohti kansanvaltaa I (Vaasa, 1975), pp. 208, 262, 268, 300.

${ }^{7}$ The class war interpretation, which emphasizes the social conflicts, is represented most clearly by Suomalainen kapitalismi (Jyväskylä, 1979). The concept class war is also used by Tandem (Juva, 1977), although it concentrates in its interpretation on higher level political events history. Suomen työväenliikkeen historia (Joensuu, 1976) differs from the aforementioned in that it consistently builds its interpretations on the concepts of revolution and counter-revolution. In terms of content the book's interpretation, however, strongly emphasizes the economic preconditions of development. 
in the discussions of the1960s concerning the need to 'objectively' evaluate the events of 1918. In this sense the project can be seen as a concluding phase of the scholarly debate on the Bolshevist influences which for long was a central thread in the historiography of the liberation war.

Especially important from this perspective is Marja-Leena Salkola's study of the formation of the Workers' and Red Guards. She explains thoroughly, almost guard by guard, the role Bolshevik and anarcho-voluntaristic thought and action played in the formative stage of the Workers' Guards. On this basis Salkola reaches the conclusion that almost without exception the formation of the guards in 1917 happened in the form of organizing unarmed security guards, which were closely linked to the activities and aims of the established local workers' organizations. ${ }^{8}$

According to Salkola although a large number of new members of the workers' movement did find their way into the Guards, the Guards' fundamental character was not a channel for spontaneous activity by unsavoury elements. The Guards were formed in conjunction with traditional workers' organizations, and their leaders and membership consisted mainly of long-time organization veterans. The arbitrary and quickly adopted Bolshevik ideals were an inaccurate reflection of most of the 1917 Guards, to say nothing of the mass movement as a whole. The mass mobilization of 1917 was as a whole channelled mostly towards the traditional vocational and political organizations of the workers' movement. ${ }^{9}$

Other studies in the History of Red Finland project concerning the period of the Red regime offer similar results. There is little evidence of Bolshevik models and influences, and, rather than spontaneity, the essential factor in bringing about the revolution proved to be the role of the traditional organizations of the workers' movement. Planning the Red government as well as local operations

${ }^{8}$ M.-L. Salkola. Työväenkaartien synty ja kehitys punakaartiksi I-II (Helsinki, 1985). A slight deviation from Salkola's views can even be seen in the summary of the series Punaisen Suomen historia [History of Red Finland]. In its concluding interpretations the Red Guards are clearly given a more active and purposeful role than what Salkola's research implies. J.T. Lappalainen, J. Piilonen, O. Rinta-Tassi, M.-L. Salkola, Yhden kortin varassa. Suomalainen vallankumous 1918 (Helsinki, 1989).

${ }^{9}$ For a summary of Salkola's research results, see M.-L. Salkola, 'Työväenkaartit ja vallankumouksellisuus 1917', Kansa liikkeessä, ed. R. Alapuro et al. (Vaasa, 1987), pp. 251-267. 
were characterized not by new revolutionary doctrines, but by the continuity of the ways of thinking and acting which had previously marked the workers' movement. This can be seen, for instance, as a tendency towards very bureaucratic forms of government and forms of exercising power on the local level. ${ }^{10}$

In a way the History of Red Finland project reset the earlier interpretations of the political background of the Finnish revolutionary movement. In a sense Salkola came to the same conclusion in regard to the masses as Soikkanen had in regard to the leaders of the workers' movement. The Bolsheviks' conscious pursuit of armed revolution, which was the central thesis in the old concept of the war of liberation, was found in neither among the leadership of the workers' movement nor in the masses. ${ }^{11}$

So who and what propelled the revolution into motion? No unambiguous answer can be found in the studies of the History of Red Finland project. The point of departure for defining the questions of the project stemmed from the 1960s effort to 'objectively' evaluate the contemporary myths; on this basis earlier conceptions were shattered rather than new interpretations of the political development which led the masses to the path to revolution being created.

A Revolution - with no Leadership and Masses? In a way this question still remains unanswered and also largely characterizes the recent discussion on the events of 1918. Risto Alapuro has sought an answer by emphasizing that the years 1917-1918 should be perceived first and foremost as a revolution, i.e. 'the kind of struggle concerning state power in which conflicts based on class are essential'. According to Alapuro, what was essential regarding the events of 1918 was the collapse of the Imperial authority and the control of means of coercion, which had started with the Russian March Revolution and escalated in the emergence of two competing power centres. In the end it was a question of an uncontrollable escalation which began with the competing powers arming themselves, rather than with the sharpening of the structural conflicts of the social or political system. ${ }^{12}$

${ }^{10}$ J.T. Lappalainen, Punakaartin sota I-II (Helsinki, 1981); J. Piilonen, Vallankumous kunnallishallinnossa (Helsinki, 1982); O. Rinta-Tassi, Kansanvaltuuskunta punaisen Suomen hallituksena (Helsinki, 1986).

${ }^{11}$ Salkola, Työväenkaartit..., II, pp. 402-410, 418-435.

${ }^{12}$ R. Alapuro, 'Kansalaissota vallankumouksena'. Sosiologia (1983); R. Alapuro, State and Revolution in Finland (Berkeley, 1988), pp. 143-196. 
To oversimplify somewhat, the Finnish revolutionary movement consisted of reformist workers' leaders who were involuntarily caught in an arms race concerning state power and rank and file members like Sillanpää's Toivolan Juha, who as individuals were carried away by the whirlwind of events that went beyond their comprehension.

Jari Ehrnrooth's interpretation of the significance of archaic hatred as the engine of the revolution can be understood in connection with this thread of discussion. It does, in fact, seem natural, almost a self-evident truth, to think that the impetus for armed revolution had to be deeply rooted in hatred on the personal level. If, however, we interpret the dynamics of the mass movement primarily on the level of mentality, and separate it from the political practice of the workers' movement, we lose the important distinction of the Finnish revolution: the essential role of the traditional organizations of the workers' movement which gave the revolution rather a bureaucratic than a spontaneous nature. ${ }^{13}$

\section{National and Popular Sovereignty and the Finnish Tradition of Organization When considering social anger as the stimulus} for the masses, we should remember that the form the revolution in Finland took was rather different from that in the other parts of the Russian Empire. In general, the revolutionary force of the Red Army consisted of the military units which had escaped or taken new command, and the local revolutionary activity resembled in many places traditional peasant uprisings with their symbolic burning of churches and manors. In Finland, organizing the seizing of power and establishing the revolutionary government on the local level were chiefly carried out by the established vocational and political organizations of the workers' movement, which had developed as part of the broader tradition of the formation of civil society and the nation. Seizing power was accomplished by separate Red Guard units, but their leaders and members were mainly recruited from old workers' organizations which had come into existence long before during peacetime.

In the Finnish political culture the organizations of civil society had since the late nineteenth century gained a strong power of legitimation as representing 'the people' and 'the will of the people'. Following the Russian Revolution the fight to represent 'the will of the people' led to the creation of two opposing organized camps in the country, and plunged them - after the collapse of Russian

${ }^{13}$ Cf. Piilonen, 1982. 
authority - into a bloody struggle for power. It is important to note, however, that this division into two had already taken place in the formative phase of the polity and the nation. The popular movements had created a nation and were now - after the collapse of the imperial power - fighting to control it.

What shook Finnish society in 1918 was not so much a spontaneous outburst of social anger, but conflicting patterns of social and political organization which, from the comparative perspective, had been exceptionally deep rooted in modern principles of national and popular sovereignty. This proved to be fatal in 1918, but in the end it was perhaps the decisive factor in stabilizing the society and solidifying the nation.

In this sense, the politics of national and popular sovereignty crossed each other in a different way than in many Central- and Eastern European countries. For instance, in Estonia the situation of 1918 appeared more self-evidently as a continuation of the national struggle for sovereignty. The forces that had formed the core of nation-building were fighting against part of the working people and the landless, who were largely left outside the development of Estonian civil society and polity and readily allied themselves with the Russian Bolsheviks. In Finland, it was more the question of popular sovereignty that set the rivalling political forces against one another. The country already had an established national political arena, which was dramatically split into two camps struggling against each other.

The internal split of society evident in the front lines of 1918 in the end might not reveal the deepest currents of the national development. The division of Finnish society was deeper because it had an established organizational basis. This division became perhaps even more overt after the civil war. In interwar Finland on the level of civil society, a Red and a White camps emerged with organizational basis that went through the society from state politics to each locality. Finland was divided into two camps that bonded the Finnish population to themselves - and in the end to the nation.

Even though these class-based camps divided the nation into two, they were part of one and the same political and social battlefield. As the right of political participation and the possibilities of representing social interests grew after 1918, they increasingly became a significant factor in the stabilization of society, and a basis for the united national front in 1939. In this sense Finnish national 
sovereignty was saved maybe less by the victory of White arms than by the same factor that plunged the country into a bloody civil war in 1918: a stronger tradition of civic organization and the adaptation of the principle of popular sovereignty as key-concept of the political culture.

\title{
Author Details
}

Ilkka Liikanen is professor of Border and Russian Studies at the Karelian Institute, University of Joensuu and the head of the Finnish national post-graduate school in Border and border Area Studies. Liikanen has studied nationalism and political mobilization in Finland, post-communist change in Russia and Estonia, and European integration and borders. Liikanen is the co-editor and co-author of Curtains of Iron and Gold. Reconstructing Borders and Scales of Interaction. (Ashgate, 1999), Education and Civic Culture in Post-Communist Countries. (Palgrave, 2001), Beyond Post-Soviet Transition. Micro Perspectives on Challenge and Survival in Russia and Estonia. (Kikimora, 2003) and Karelia - a Cross-border Region? The EU and Cross-border Region-building on the Finnish-Russian Border. (Karelian Institute, 2007).

Email: ilkka liikanen@joensu.fi

\author{
VALSTYBĖS IR VISUOMENĖS SUVERENITETAS \\ SUOMIJAI ATGAUNANT NEPRIKLAUSOMYBE IR \\ KARIAUJANT 1918 M. PILIETINIAME KARE
}

Santrauka

\section{ILKKA LIIKANEN}

Šiuo darbu siekiama apibendrinti pagrindines akademinès diskusijos dèl Suomijos pilietinio karo kryptis. Straipsnyje šiuolaikinès politikos požiūriu keliami keletas su konflikto pobūdžiu susijusių klausimų. Atsižvelgiant ị neseniai vykusią diskusiją dẻl šiuolaikinès politinès kultūros prieštaravimų, keliamas klausimas, kokiu mastu karas gali būti suprantamas prieštaraujančių valstybės ir visuomenès suvereniteto pavyzdžių kontekste.

Tarpukario laikotarpiu ir Šaltojo karo metu 1918 m. pilietinio karo pobūdis istoriografiniu požiūriu buvo apibrěžtas iš esmès dviem skirtingais būdais. Remiantis vyraujančia akademine tradicija, karas buvo aiškinamas kaip kova už valstybinị (nacionalini) suvereniteta, t. y. kaip ,išsivadavimo karas“. Kalbant apie darbo jègos judejjimą, konfliktas buvo modeliuojamas kaip vidaus klausimas, kaip socialinis konfliktas arba „klasių karas“. Nuo XX a. septintojo dešimtmečio ėmè rastis naujų interpretacijų, kuriomis buvo bandoma ir apibūdinti krizes, ir suvokti karą kaip kovą už nacionalinį suvereniteta, taip pat - kokiu mastu jis gali būti aiškinamas vidaus socialinio ir politinio konflikto kontekste. 